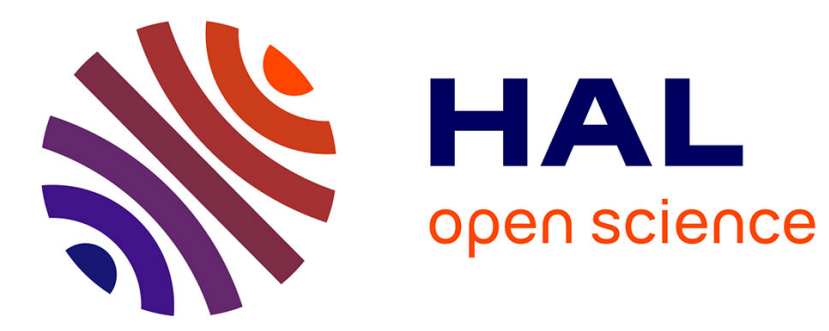

\title{
Phosphorus acquisition from phytate depends on efficient bacterial grazing, irrespective of the mycorrhizal status of [i]Pinus pinaster[/i]
}

Usman Irshad, Alain Brauman, Cecile Villenave, Claude Plassard

\section{To cite this version:}

Usman Irshad, Alain Brauman, Cecile Villenave, Claude Plassard. Phosphorus acquisition from phytate depends on efficient bacterial grazing, irrespective of the mycorrhizal status of [i]Pinus pinaster[/i]. Plant and Soil, 2012, 358 (1-2), pp.148-161. 10.1007/s11104-012-1161-3 . hal-01267974

\section{HAL Id: hal-01267974 \\ https://hal.science/hal-01267974}

Submitted on 29 May 2020

HAL is a multi-disciplinary open access archive for the deposit and dissemination of scientific research documents, whether they are published or not. The documents may come from teaching and research institutions in France or abroad, or from public or private research centers.
L'archive ouverte pluridisciplinaire HAL, est destinée au dépôt et à la diffusion de documents scientifiques de niveau recherche, publiés ou non, émanant des établissements d'enseignement et de recherche français ou étrangers, des laboratoires publics ou privés. 


\title{
Phosphorus acquisition from phytate depends on efficient bacterial grazing, irrespective of the mycorrhizal status of Pinus pinaster
}

\author{
Usman Irshad • Alain Brauman • Cécile Villenave • Claude Plassard
}

Received: 27 October 2011 / Accepted: 30 January 2012 / Published online: 8 March 2012

(C) Springer Science+Business Media B.V. 2012

\begin{abstract}
Background and aims Phosphorus from phytate, although constituting the main proportion of organic soil $\mathrm{P}$, is unavailable to plants. Despite the well-known effects of rhizosphere trophic relationships on $\mathrm{N}$ mineralization, no work has been done yet on P mineralization. We hypothesized that the interactions between phytate-mineralizing bacteria, mycorrhizal fungi and bacterial grazer nematodes are able to improve plant $\mathrm{P}$ use from phytate.

Methods We tested this hypothesis by growing Pinus pinaster seedlings in agar containing phytate as $\mathrm{P}$ source. The plants, whether or not ectomycorrhizal with the basidiomycete Hebeloma cylindrosporum, were grown alone or with a phytase-producing bacteria $\mathrm{Ba}$ cillus subtilis and two bacterial-feeder nematodes, Rhabditis sp. and Acrobeloides sp. The bacteria and the nematodes were isolated from ectomycorrhizal roots and soil from $P$. pinaster plantations.

Results Only the grazing of bacteria by nematodes enhanced plant $\mathrm{P}$ accumulation. Although plants increased
\end{abstract}

Responsible Editor: Megan H. Ryan.

Electronic supplementary material The online version of this article (doi:10.1007/s11104-012-1161-3) contains

supplementary material, which is available to authorized users.

U. Irshad $\cdot$ C. Plassard $(\bowtie)$

INRA, UMR 1222 Eco\&Sols,

Montpellier Cedex 01, France

e-mail: plassard@supagro.inra.fr

A. Brauman $\cdot$ C. Villenave

IRD, UMR 1222 Eco\&Sols,

Montpellier Cedex 01, France the density of phytase-producing bacteria, these bacteria alone did not improve plant $\mathrm{P}$ nutrition. The seedlings, whether ectomycorrhizal or not, displayed a low capacity to use P from phytate.

Conclusions In this experiment, the bacteria locked up the phosphorus, which was delivered to plant only by bacterial grazers like nematodes. Our results open an alternative route for better utilization of poorly available organic $\mathrm{P}$ by plants.

Keywords Phytase $\cdot$ Ectomycorrhiza $\cdot$ Root architecture - Bacillus subtilis · Hebeloma cylindrosporum $\cdot$ Rhabditidae $\cdot$ Cephalobidae

\section{Introduction}

Phosphorus $(\mathrm{P})$ is of vital importance for plant production due to the plant metabolic requirements for growth and replication. However, $\mathrm{P}$ is taken up by plants and microorganisms only as orthophosphate $(\mathrm{Pi})$, represented by the anion $\mathrm{H}_{2} \mathrm{PO}_{4}{ }^{-}$and $\mathrm{HPO}_{4}{ }^{2-}$. Due to its strong capacity to make complexes with cations and to its low mobility, concentrations of free $\mathrm{Pi}$ in the soil solution are generally low and estimated between 1 to $10 \mu \mathrm{M}$ (Hinsinger 2001). Therefore, P limits the productivity of plants in many terrestrial ecosystems and is often the first or second element limiting aboveground net primary productivity of forests (Plassard and Dell 2010).

Remarkably, besides the low level of available free $\mathrm{Pi}$, soils contain a high amount of $\mathrm{P}$ that is linked to $\mathrm{C}$ containing compounds to form organic $\mathrm{P}(\mathrm{Po})$. Typically, Po contributes from $30-65 \%$, sometimes $>90 \%$, of the 
total soil P (Harrison 1987) and is present under a wide range of compounds, including mono- and di-phosphate esters. Among these Po compounds, myo-inositol hexakisphosphate (phytate) holds a particular place as it has been found to accumulate in soil (Turner et al. 2002; Turner 2007) indicating that it may be difficult to degrade either by roots or soil organisms. This form of phosphorus is found in many ecosystems, including forest ecosystems (Turner et al. 2002; Turner, 2007). Finding strategies to increase the use of $\mathrm{P}$ contained in phytate by plants is of particular importance because this Po form, making up $65-75 \%$ of $\mathrm{P}$ in the seeds of cereals or legumes (Raboy 2007), is also one of the primary $P$ species of manure produced by monogastric animals (Peperzak et al. 1959; Barnett 1994; Turner and Leytem 2004). Such a strategy would increase the recycling of $P$ to enhance or maintain plant production while decreasing the use of mineral $\mathrm{P}$ of which high grade phosphate rocks are definitely expected to be exhausted within decades from now; (Cordell et al. 2009).

To be used by plants and microorganisms, phosphate groups of phytate must be released by phytases. Based on their structural differences and varied catalytic properties, four classes of phytases have been proposed. These include (1) members of histidine acid phytases (HAP), found in fungi, plants and bacteria (2) B-Propeller phytase (BPP) found in bacteria, especially in Bacillus sp., (3) cysteine phytase (CPhy) found in bacteria from anaerobic environments and (4) purple acid phytase (PAP) found in plants (Mullaney and Ullah 2003, 2007). The ability to mobilise phytate in soil solution will rely on the capacity of organisms to produce the enzymes into the external medium or at least in the cell wall space. Up to now, plants grown in axenic conditions have been shown to exhibit a poor capacity to use phytate as the sole source of P (Hayes et al. 2000; Richardson et al. 2000, 2001a; Richardson et al. 2001b ) suggesting a low capacity to release phytase into the external medium. This low capacity seems shared by the ectomycorrhizal species as data obtained so far (Mousain et al. 1988; Louche et al. 2010) indicated that phytase from these symbiotic fungi represent only a small fraction of their total phosphatase activity.

The first strategy used to enhance plant access to $\mathrm{P}$ from phytate was gene technology through plant transformation with phytase genes of fungal (Aspergillus niger-Richardson et al. 2001a) or bacterial (Bacillus subtilis $\beta$-propeller-Yip et al. 2003) origin. Transgenic plants were able to produce phytase activity in their external medium and to take up significant amounts of $\mathrm{P}$ from phytate. However, this strategy is not always sucessful when plants are grown in soil (George et al. 2005; Richardson et al. 2007). In addition, it is only applicable to plants easily transformable and could thus be limited to these species.

Another strategy that has not been studied yet would rely on the exploitation of the interactions between plants, mycorrhizal fungi, bacteria and their grazers in the rhizosphere - the food web relationships - combined with the bacterial ability to degrade phytate. Plant rhizosphere was shown to contain bacteria able to mineralize phytate in vitro (Jorquera et al. 2008a,b) and plant inoculation with bacteria able to degrade phytate in pure culture was shown to increase plant access to $\mathrm{P}$ from myo-inositol hexakisphosphate (Richardson and Hadobas 1997; Hayes et al. 2000; Richardson et al. 2001b). However, this positive effect of plant inoculation by phytate-using bacteria could be strongly increased by the presence of bacterial grazers, through the microbial loop in which plant exudates stimulate bacterial growth that will in turn liberate nutrients through their grazing by bacterial grazers. In addition to the bacteria, mycorrhizal fungi could also exert a positive role by enhancing the soluble mineral $\mathrm{P}$ uptake by the host plant from the supplementary P released into the medium (Plassard and Dell 2010; Smith et al. 2011, Tatry et al. 2009).

Of the bacterial grazers, protozoa and nematodes have been shown to play a major role releasing nutrients sequestered in the bacterial biomass in the rhizosphere, especially regarding N cycling (Bonkowski et al. 2009; Villenave et al. 2004). However the contribution of soil fauna to the release of $\mathrm{P}$ from the microbial biomass has not yet been determined (Marschner et al. 2011). Elucidation of the possible role of the food web on P cycling from recalcitrant organic $\mathrm{P}$ sources such as phytate through the activity of bacterivorous nematodes appears highly relevant as these organisms are a major component of the food web in the soil, especially in forest situations. For example, of the whole nematode population extracted from a mixed deciduous forest, 20-50\% of nematodes were bacterial-feeders (Bernard 1992). Furthermore, recent studies showed that the proportion of bacterial-over fungal-feeder nematodes increased with root densities of two perennial species, tending to values ranging from 0.7 (Pinus nigra) to 0.9 (Kunzea ericoides) (Dickie et al. 2011), underlying the importance of the bacterial compartment in these conditions. Despite this ecological significance, the impact of 
predation on $\mathrm{P}$ cycle at the rhizosphere level has been nearly been ignored so far (Ingham et al. 1985).

In this work, we hypothesized that the interactions between phytate mineralizing bacteria and mycorrhizal fungi together with bacterial grazer nematodes are able to improve plant $\mathrm{P}$ use from phytate. We tested this hypothesis by growing Pinus pinaster seedlings in agar containing phytate as P source. Plants, whether or not associated with the ectomycorrhizal basidiomycete Hebeloma cylindrosporum, were grown alone or with a phytase-producing bacteria Bacillus subtilis and two bacterial grazer nematodes belonging to Rhabditis sp. and Acrobeloides sp. The bacteria and the nematode were isolated from ectomycorrhizal roots and soil from $P$. pinaster plantations.

\section{Material and methods}

Fungal and plant material

A dikaryotic strain (D2) of the ectomycorrhizal basidiomycete Hebeloma cylindrosporum Romagnesi, resulting from the plasmogamy of the two compatible homokaryotic strains (h1 and h7) (Debaud and Gay 1987) was used. Mycelia were grown in the dark, at $24^{\circ} \mathrm{C}$ in standard nitrate (N6) medium, either on agar-solidifiedmedium or in liquid culture without shaking (Louche et al. 2010). Seedlings of maritime pine (Pinus pinaster Soland in Ait. from Medoc, Landes-Sore-VG source, France) were obtained from germination of seeds carried out in sterile conditions (Irshad et al. 2011). Mycorrhizal synthesis was performed in test tubes (Casarin et al. 2004) and plants, whether inoculated or not, were placed in a growth chamber under the same conditions as described in Ali et al. (2009) for two months before the coinoculation experiment.

\section{Bacterial strain and nematodes}

The bacterial strain used, Bacillus subtilis, was isolated from Pine roots and maintained in pure culture as described previously (Irshad et al. 2011). For inoculation experiment, bacteria were grown in shaken conditions $(150 \mathrm{rpm})$ at $28^{\circ} \mathrm{C}$ for $40 \mathrm{~h}$ in the synthetic medium (Irshad et al. 2011) excepted that $\mathrm{N}$ and $\mathrm{P}$ sources were supplied as $1 \mathrm{mM} \mathrm{KNO}$ and $0.2 \mathrm{mM} \mathrm{KH}_{2} \mathrm{PO}_{4}$. At maximum optical density $(600 \mathrm{~nm})$, the cultures were centrifuged (5000 g, $10 \mathrm{~min}$ ) and the pellet was washed twice in sterile deionized water to eliminate any remaining $\mathrm{P}$. The bacteria were then re-suspended in $30 \mathrm{ml}$ of sterile deionized water before use. Cell density of this solution was determined using a dilution 1/1000 deposited on a hemocytometer $(0.2 \mathrm{~mm}$ depth). Calculations of bacterial density were performed using the link http:// www.changbioscience.com/cell/hemo.html. Unless differently stated, the initial bacterial density of the solution used to inoculate plates was $1.3 \times 10^{6} \mathrm{cells} \mathrm{ml}^{-1}$.

Monoxenic populations of nematodes were obtained following the method previously described (Irshad et al. 2011). Here, we used two nematode species identified from molecular analysis of $18 \mathrm{~S}$ rDNA gene as Rhabditis sp. (Irshad et al. 2011) and Acrobeloides $\mathrm{sp}$ (this study). After multiplication in dark at $24^{\circ} \mathrm{C}$, the nematodes were washed from most $B$. subtilis by centrifugation ( $1000 \mathrm{rpm}, 5 \mathrm{~min}$ ) and re-suspended in sterile deionized water to a density of $214 \pm 12$ (Rhabditis sp.) and 196 \pm 10 (Acrobeloides sp.) nematodes $\mathrm{ml}^{-1}$ for inoculation in plates.

Experimental design for co-inoculation

Plants of two status, either non-mycorrhizal (NM) or mycorrhizal (M) with $H$. cylindrosporum, were then set up with three inoculation treatments: (1) no inoculation (none), (2) inoculation with B. subtilis (+bac), and (3) inoculation with $B$. subtilis and Rhabtidis sp. (+bac+nem1) or Acrobeloides sp. (+bac+nem2). The experiment was carried out in square Petri dishes and growth conditions described in Irshad et al. (2011) for two months. The nutrient medium (70 ml/dish) contained 1.0\% agarose (Eurobio Molecular Biology Grade), $2 \mathrm{mM} \mathrm{MgSO}_{4} \cdot 7 \mathrm{H}_{2} \mathrm{O}, 4 \mathrm{mM} \mathrm{CaSO}_{4}$, $50 \mu \mathrm{g} \mathrm{l}^{-1}$ thiamine hydrochloride, $0.5 \mathrm{ml} \mathrm{l}^{-1} 1 \% \mathrm{Fe}$ citrate, $50 \mathrm{mM}$ MOPS, $0.2 \mathrm{ml} \mathrm{l}^{-1}$ Morizet and Mingeau solution of micronutrients (1976), $2 \mathrm{mM} \mathrm{KNO}_{3}$ as the sole source of N, $1 \mathrm{mM}$ phytate (inositol hexakisphosphate, sodium salt, Sigma, ref P0109) and cholesterol $\left(5 \mu \mathrm{g}^{-1}\right)$. The medium without phytate and cholesterol was autoclaved $\left(115^{\circ} \mathrm{C}, 40 \mathrm{~min}\right)$ and cooled to $55^{\circ} \mathrm{C}$ before adding filtered $(0.2 \mu \mathrm{m}$ pore size $)$ sterilized solution of phytate and cholesterol. Before the experiment, agarose and phytate were checked for their free Pi contents that were $43.4 \mu \mathrm{g} \mathrm{P} \mathrm{g}{ }^{-1}$ dry wt of agarose and $182.1 \mu \mathrm{g} \mathrm{P} \mathrm{mmol}{ }^{-1}$ of phytate. Taken together, the solid medium contained $43 \mu \mathrm{g}$ free Pi plate ${ }^{-1}$. After solidification, plates from both NM and $\mathrm{M}$ treatments, (+bac) as well as $(+\mathrm{bac}+$ nem $)$ treatment, 
received $1 \mathrm{ml}$ of bacterial suspension (equal to $1.3 \pm$ $0.1 \times 10^{6}$ cells plant $\left.^{-1}\right)$. On top of that, plates from treatment $(+\mathrm{bac}+\mathrm{nem})$ received $0.5 \mathrm{ml}$ of nematode suspension (equal to $107 \pm 6$ and $98 \pm 5$ nematodes plant $^{-1}$ for Rhabditis sp. and Acrobeloides sp., respectively). Both of these inoculums contributed a negligible amount of free Pi $\left(1.53 \mu \mathrm{g} / \mathrm{plant}^{-1}\right)$. Each plate from treatments without bacteria and nematodes (none) received $1.5 \mathrm{ml}$ sterile deionized water to give the same level of moisture to all plants.

Use of phytate by the fungus, the bacteria and the nematodes without plant

To check their capacity to use phytate as a source of $\mathrm{P}$, the fungus and the bacteria were grown in pure culture. $H$. cylindrosporum was grown in a flask containing $40 \mathrm{ml}$ of liquid medium of the same composition as the coinoculation medium supplemented with $55 \mathrm{mM}$ glucose. Phosphorus was added either as $\mathrm{KH}_{2} \mathrm{PO}_{4}(1 \mathrm{mM})$ or phytate $(1 \mathrm{mM})$. The fungus was grown for 24 days in the dark, as described above. The cultures of $B$. subtilis were also carried out in liquid medium of the same composition as the co-inoculation medium supplemented with $55 \mathrm{mM}$ glucose and with $\mathrm{P}$ either as $\mathrm{KH}_{2} \mathrm{PO}_{4}$ $(1 \mathrm{mM})$ or sodium phytate $(6 \mathrm{mM})$. The bacteria were grown at $28^{\circ} \mathrm{C}$, with shaking $(150 \mathrm{rpm})$ for $120 \mathrm{~h}$.

We also checked the capacity of the bacteria and their grazers (Rhabditis sp.) to develop in the co inoculation medium, supplied in the same conditions as for plant culture, with no additional $\mathrm{C}$ source added to the solid medium. Square Petri dishes containing $70 \mathrm{ml}$ of solid medium with $1 \mathrm{mM}$ phytate were inoculated with bacteria $\left(1.3 \pm 0.1 \times 10^{6}\right.$ bacteria plate $\left.^{-1}\right)$ only or with bacteria and nematodes ( $107 \pm 6$ individuals plate $\left.{ }^{-1}\right)$, as described previously for plants. The plates were sealed with sticky tape and placed in the growth chamber and protected from light. They were used to measure the bacterial and nematode populations after every two weeks until 60 days of incubation ( $n=3$ plates/time/treatment).

\section{Plant analysis}

Root parameters (length, surface area, number of tips and forks) were measured on cleaned root systems scanned with the software WinRHIZO (http://www.regentinstru ments.com/products/rhizo/Rhizo.html). Shoots (needles plus stem) and roots were freeze-dried for dry biomass determination and were then milled before carrying out $P$ determination and chitin assay. Total $\mathrm{P}$ contents were determined after mineralization of tissues with $\mathrm{H}_{2} \mathrm{SO}_{4}$ $36 \mathrm{~N}$ as described in Aquino and Plassard (2004). Free orthophosphate concentration was assayed in mineralized solution according to Ohno and Zibilske (1991) with malachite green. All these analyses were carried out first on 2-month old NM and M plants (data given in Table S1) used to set up the inoculation experiment and at the end of the experiment. Chitin assay was performed at the end of the experiment on $10 \mathrm{mg}$ of roots heated in $1 \mathrm{ml}$ of $6 \mathrm{~N} \mathrm{HCl}$ according to the method from Vignon et al. (1986) and fully described in supplementary material.

Bacterial and nematode populations

The solid medium of each Petri dish was first cut into pieces and transferred to sterile $180 \mathrm{ml}$-polypropylene containers with $10 \mathrm{ml}$ of deionized sterile water in sterile conditions. Each container was shaken by hand for $5 \mathrm{~min}$ and aliquot of solution $(1 \mathrm{ml})$ was taken after $2 \mathrm{~h}$. This solution was used to numerate bacterial cells with a hemocytometer after adequate dilution (at least $1 /$ 10000). The remaining solution and solid medium were then transferred on a filter paper for $48 \mathrm{~h}$ to collect the population of living nematodes that moved through the filter into the water $(50 \mathrm{ml})$ beneath. The nematodes were further concentrated by gravitation in a fraction of $5 \mathrm{ml}$. They were counted immediately by using a stereomicroscope to determine the final density and then fixed to determine their biomass. Fixation was carried out by mixing fixation solution ( $4 \%$ formaldehyde) heated at $70^{\circ} \mathrm{C}$ with the solution containing the nematodes $(10 / 1, v / v)$. Slides were then made and observed under microscope. The dimensions (width and length) of nematodes were recorded using the software cell B ((http:// www.microscopy.olympus.eu/microscopes/Software cell_B.htm). The body weight $(\mu \mathrm{g})$ of each individual was calculated using a formula derived by Andrassy (Andrassy 1956 in Zuckerman et al. 1967):

Body weight of nematodes $(\mu g)=\mathrm{a}^{2} \times \mathrm{b} / 1600000$

where $\mathrm{a}$ is the greatest body width and $\mathrm{b}$ the length in micrometers.

Statistical analysis

Unless otherwise stated, the results are given as mean \pm standard deviation ( $n=6$ at T0 and 7 at the end 
of experiment). The differences between means were analyzed by factorial ANOVA followed by Tukey's HSD post-hoc test using Statistica 7.1 (StatSoft Inc., Tulsa, OK, USA). Normality was tested using the Kolmogorov Smirnov test and, where necessary, the data was either square root or $\log 10$ transformed prior to analysis to meet the assumptions of ANOVA. The comparison of means between NM and $\mathrm{M}$ samples at the beginning and the end of experiment was carried out using the Student's t test.

\section{Results}

Use of phytate by microbial partners in pure culture

The growth and total $\mathrm{P}$ accumulation measured in $H$. cylindrosporum thalli displayed huge differences when grown for 24 days in the same liquid medium containing either soluble orthophosphate $(\mathrm{Pi})$ or phytate as the sole source of $\mathrm{P}$ (Table S2). Biomass production, total $\mathrm{P}$ contents and accumulation in Pi-grown mycelia were $5,1.5$ and 8 times higher than in phytate-grown mycelia, respectively (Table S2). In addition, the amounts of $\mathrm{P}$ accumulated in phytate-grown mycelia (on average $33 \mu \mathrm{g}$ total P per thallus) were of the same order of magnitude as the $\mathrm{P}$ contamination brought by phytate salt ( $7 \mu \mathrm{g}$ per flask) and agar plug ( $23 \mu \mathrm{g}$ per flask). Taken together, these results indicated that the fungus displayed a poor ability to use phytate as a $\mathrm{P}$ source. The bacteria $B$. subtilis were able to grow whatever the $\mathrm{P}$ source supplied into the medium (Fig. S1). Although phytate-grown bacteria grew 33\% less than Pi-grown bacteria, they were able to increase external [Pi] in the medium in addition to their own growth (Fig. S1b). These results confirmed the phytate-mineralizing capacity of this bacterial strain.

As shown in Table 1, bacterial populations increased by a factor of around 6 after only 15 days of incubation. They remained stable over the last 45 days, with or without the bacterial-feeding nematodes $R h a b$ ditis sp., although the presence of nematodes significantly increased the number of bacterial populations after 60 days of incubation. Similarly to that of bacteria, the population of active nematodes dramatically increased by a factor of 10 during the first 15 days of incubation. After this peak of growth, nematode abundance did not change significantly with incubation time (Table 1).
Effect of food web complexity on root development, plant growth and mineral nutrition

Whatever the treatment, the plants displayed a significant root development as all values of root parameters (length, surface area, number of tips and forks) measured in plants sampled at the time of transfer to the phytate-containing medium were significantly lower than those measured at the end of experiment (Table 2). The values of root parameters recorded at the end of experiment were first analyzed using two-way ANOVA showing that there was no interaction between plant status and inoculation treatments on all parameters measured except the numbers of root tips (Table 2). Generally speaking, plant status induced a significant effect on root growth, as all parameters measured in NM plants were higher than those measured in $\mathrm{M}$ plants (Table 2). Conversely, inoculation treatments induced a significant effect on root parameters due to a positive effect of nematodes on root extension assessed by length, surface area and ramification degree given by tip and fork numbers. More precisely, in non-mycorrhizal plants, nematode activity induced a significant increase of root length ( $+30 \%$ and $+34 \%$, for Rhabditis sp. and Acrobeloides sp., respectively) and root surface area $(+54 \%$ for $R h a b$ ditis sp. only) compared to the average value of sterile and +bacteria plants (Table 2). However, nematode activity induced a significant increase of root ramification compared only to the +bacteria treatment as the numbers of tips and forks were increased respectively by $31-27 \%$ (Rhabditis sp.) and by 46-36\% (Acrobeloides sp.). In contrast, inoculation treatments did not modify the root parameters measured in $\mathrm{M}$ plants, except the number of tips that was significantly enhanced by $+59 \%$ (Rhabditis sp.) and $+84 \%$ (Acrobeloides sp.) by nematodes compared to sterile M plants.

In agreement with root development, root dry matter was increased in all plants during the culture on phytatecontaining medium compared to the initial root dry weight of plants (Fig. 1a). In contrast, shoot dry biomass was not significantly increased in all treatments, as sterile NM or M plants, and M plants with bacteria did not produce shoot growth. Only the presence of Rhabditis sp. induced a high production of shoot biomass in $\mathrm{NM}$ and in M plants (Fig. 1a). Statistical analysis showed that the plant status did not modify root or shoot dry weights, contrary to the inoculation treatments which induced strong changes in root and shoot growth (Table 3, Fig. 1a). Indeed, the plants, whether or not 
Table 1 Evolution of populations of phytate mineralizing bacteria (Bacillus subtilis) and their nematode grazer (Rhabditis sp.) in solid medium grown in sterile conditions containing phytate as the sole source of $\mathrm{P}$ and $\mathrm{C}$. The initial populations were $1.3 \times$ $10^{6} \pm 0.1$ bacteria and $107 \pm 7$ nematodes per plate

\begin{tabular}{lllllll}
\hline & Days & 15 & 30 & 45 & 60 & $P$-value \\
\hline Bacterial cells $\left(\times 10^{6}\right.$ plate $\left.^{-1}\right)$ & none & ND & ND & ND & ND & \\
& + bac & $6.3 \pm 0.6 \mathrm{a}^{\mathrm{A}}$ & $6.0 \pm 0.3 \mathrm{~b}^{\mathrm{A}}$ & $6.4 \pm 0.1 \mathrm{a}^{\mathrm{A}}$ & $6.4 \pm 0.3 \mathrm{~b}^{\mathrm{A}}$ & $>0.05$ \\
& + bac + nem & $6.7 \pm 0.4 \mathrm{a}^{\mathrm{A}}$ & $6.9 \pm 0.3 \mathrm{a}^{\mathrm{A}}$ & $6.9 \pm 0.9 \mathrm{a}^{\mathrm{A}}$ & $7.5 \pm 0.1 \mathrm{a}^{\mathrm{A}}$ & $>0.05$ \\
& $P$-value & $>0.05$ & $<0.01$ & $>0.05$ & $<0.01$ & $0.92 \pm 0.33^{\mathrm{A}}$ \\
Nematodes $\left(\times 10^{3}\right.$ plate $\left.^{-1}\right)$ & + bac + nem & $1.03 \pm 0.21^{\mathrm{A}}$ & $0.82 \pm 0.18^{\mathrm{A}}$ & $0.87 \pm 0.44^{\mathrm{A}}$ & 0.05 \\
\hline
\end{tabular}

Data are means \pm standard deviation $(n=3)$. Different small letters denote significant effect of inoculation treatments and capital letters denote significant effect of time given by one-way ANOVA followed by the Tukey's minimum significant difference test

mycorrhizal, accumulated the same amounts of root and shoot dry biomass when grown in sterile conditions or with bacteria only. Compared to the averaged amounts of biomass calculated in the plants grown in sterile conditions or with bacteria alone, only the presence of Rhabditis sp. induced a strong increase of both roots $(+44 \%)$ and shoots $(+50 \%)$ in NM plants and only a significant biomass increase $(+38 \%)$ of shoots in $\mathrm{M}$ plants (Fig. 1a).

Total $\mathrm{P}$ accumulation was significantly increased in all plants grown in phytate-containing medium compared to the $\mathrm{P}$ amounts accumulated in plants at the time of transfer except in the M plants inoculated with bacteria (Fig. 1b). As was the case for biomass accumulation,
Table 2 Root growth parameters (length, surface area, number of tips and forks) measured in $P$. pinaster plants of different status, either non-mycorrhizal (NM) or mycorrhizal (M) with the ectomycorrhizal fungus $H$. cylindrosporum. Two-month old plants were supplied with phytate in solid medium for $60 \mathrm{~d}$ and received different inoculation treatments that were either no addition (none), or addition of a phytate-mineralizing bacteria only, B. subtilis (+bac) or of the bacteria with the bacteria-feeding nematodes, Rhabditis sp. (+bac+nem1) or Acrobeloides sp. (+bac +nem2)

\begin{tabular}{|c|c|c|c|c|c|}
\hline Plant status & $\begin{array}{l}\text { Inoculation } \\
\text { treatments }\end{array}$ & $\begin{array}{l}\text { Length } \\
\left.\text { (cmplant }^{-1}\right)\end{array}$ & $\begin{array}{l}\text { Surface area } \\
\left(\mathrm{cm}^{2} \text { plant }^{-1}\right)\end{array}$ & $\begin{array}{l}\text { Tips } \\
\text { (number plant }^{-1} \text { ) }\end{array}$ & Forks \\
\hline \multirow[t]{4}{*}{ NM } & none & $588 \mathrm{abc}$ & $135 b$ & $2559 \mathrm{bc}$ & $5554 \mathrm{ab}$ \\
\hline & + bac & $527 \mathrm{bc}$ & $136 b$ & $2363 \mathrm{~cd}$ & $4930 b$ \\
\hline & $+\mathrm{bac}+$ nem 1 & $722 \mathrm{a}$ & $211 \mathrm{a}$ & $3099 \mathrm{ab}$ & $7074 a$ \\
\hline & + bac + nem 2 & $745 \mathrm{a}$ & $180 \mathrm{ab}$ & $3452 \mathrm{a}$ & $6723 a$ \\
\hline \multirow[t]{4}{*}{ M } & none & $448 b$ & $128 b$ & $1869 d$ & $3895 b$ \\
\hline & + bac & $481 \mathrm{bc}$ & $127 \mathrm{~b}$ & $2546 \mathrm{bc}$ & $4718 b$ \\
\hline & + bac + nem 1 & $577 \mathrm{abc}$ & $152 b$ & $3009 \mathrm{ab}$ & $5318 b$ \\
\hline & $+\mathrm{bac}+$ nem 2 & $635 \mathrm{ab}$ & $147 \mathrm{~b}$ & $3448 \mathrm{a}$ & $5446 \mathrm{ab}$ \\
\hline \multicolumn{2}{|c|}{ One-way ANOVA $P$-value } & $<0.01$ & $<0.01$ & $<0.01$ & $<0.01$ \\
\hline \multicolumn{6}{|c|}{ Two-way ANOVA $P$-values } \\
\hline \multicolumn{6}{|c|}{ Variation source } \\
\hline \multicolumn{2}{|l|}{ Plant status } & $<0.01$ & $<0.01$ & $>0.05$ & $<0.01$ \\
\hline \multicolumn{2}{|c|}{ Inoc. treatments } & $<0.01$ & $<0.01$ & $<0.01$ & $<0.01$ \\
\hline \multicolumn{2}{|l|}{ Interaction } & $>0.05$ & $>0.05$ & $<0.05$ & $>0.05$ \\
\hline
\end{tabular}

Data are means $(n=7)$ and were compared using one-way ANOVA followed by the Tukey's minimum significant difference test. For each parameter, means significantly different at $P<0.05$ have different letters. A two-way ANOVA was also performed to assess the individual and combined effects of plant status and inoculation treatments using the Tukey's minimum significant difference test. All the parameters differed significantly from the means measured in plants sampled before the experiment and given in Table S1 (comparison of means, Student's $t$ test) 
Fig. 1 Biomass (a) and $\mathrm{P}$ (b) accumulation in $P$. pinaster plants, not associated (NM) or associated (M) with the ectomycorrhizal basidiomycete Hebeloma cylindrosporum and cultivated with different inoculation treatments: without any addition of supplementary organisms (none), addition of a phytate-

mineralizing bacteria Bacillus subtilis (+bac), or addition of the bacteria together with the bacteria-feeding nematodes Rhabditis sp. (+bac+nem1) or Acrobeloides sp. (+bac+nem2). Two-month old plants were grown for $60 \mathrm{~d}$ with phytate as the sole source of $\mathrm{P}$ in solid medium. Bars correspond to means $(n=7)$. Different letters indicate different means at $P<0.05$ (one-way ANOVA followed by the Tukey's minimum significant difference test). Asterisk indicates a mean significantly different from the initial value measured in two-month old plants at $P<$ 0.05 (Student's t-test of mean comparison) (a) $\square$ none $\square$ +bac $\square+$ +bac+nem1 $\mathbf{\square}+$ +bac+nem2

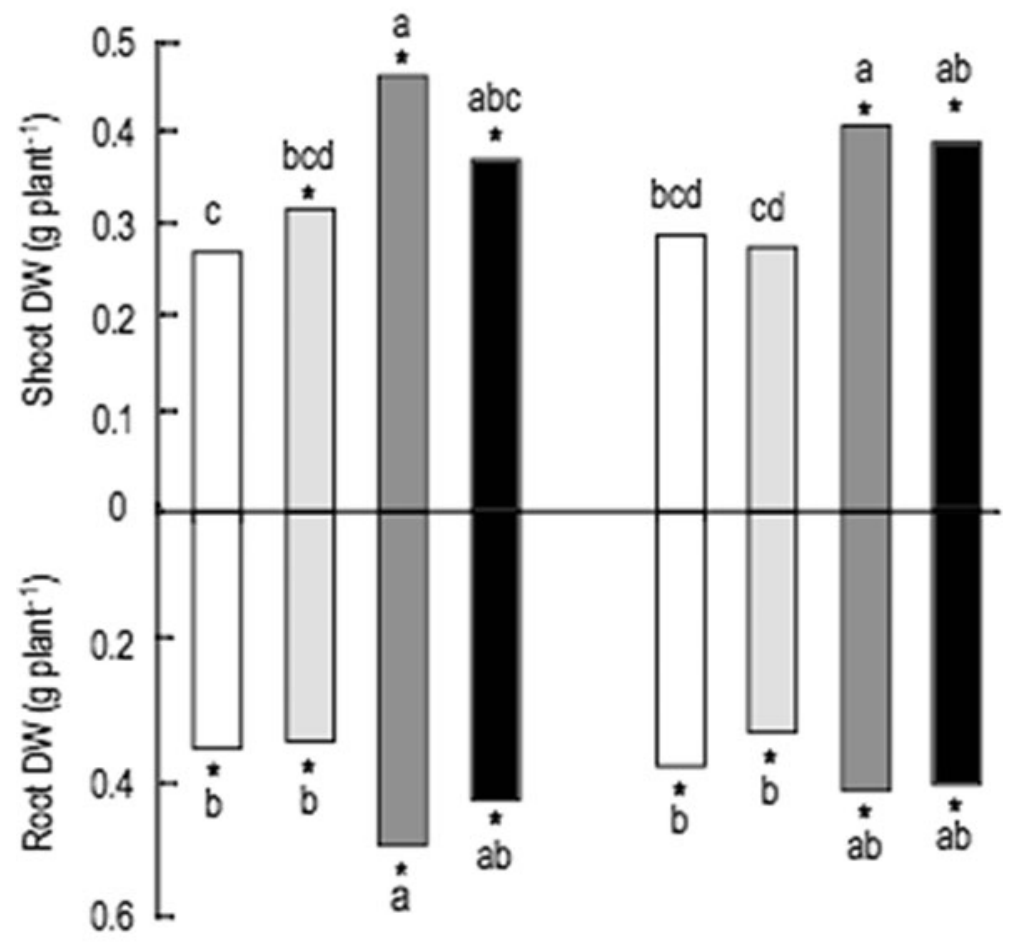

(b)

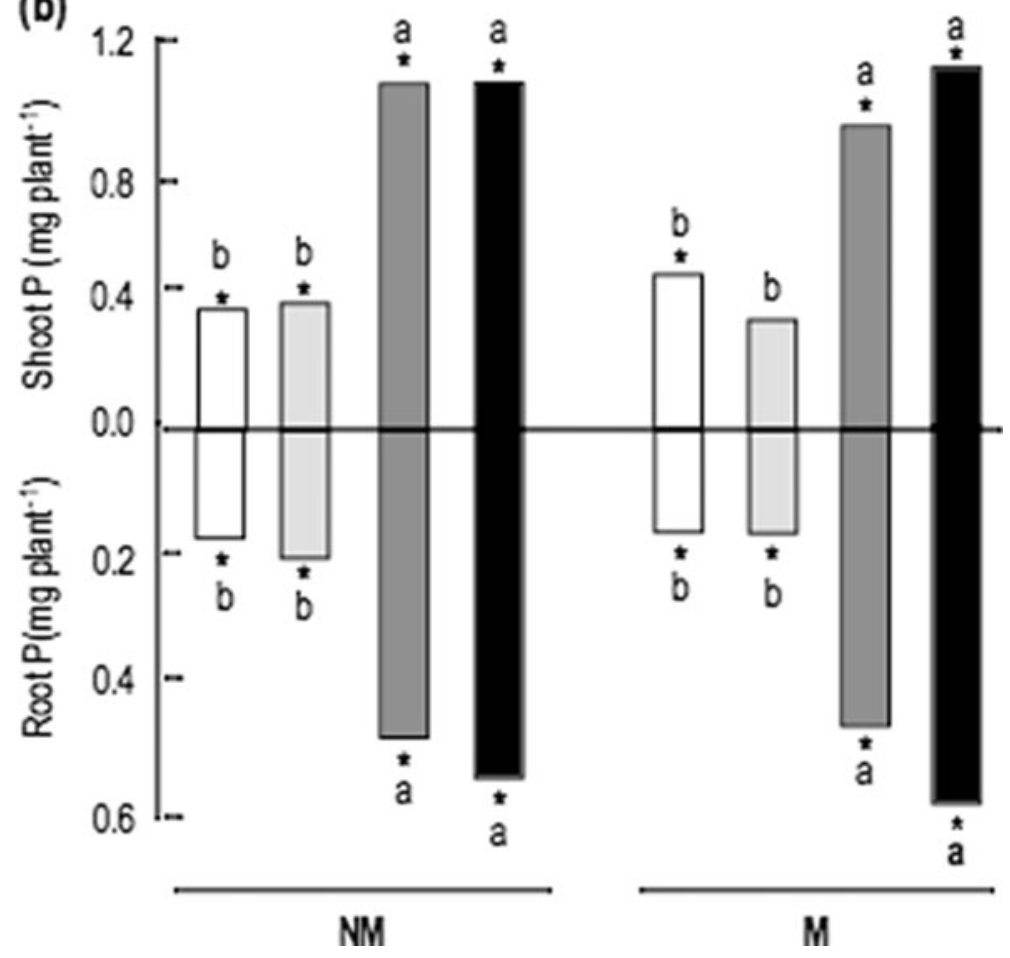


Table 3 ANOVA table of $P$-values on the effect of plant status (non-mycorrhizal or mycorrhizal with the ectomycorrhizal fungus $H$. cylindrosporum) or inoculation treatments (no addition, addition of a phytate-mineralizing bacteria $B$. subtilis or addition of $B$. subtilis plus the bacteria-feeding nematodes, Rhabditis sp. (+bac+nem1) or Acrobeloides sp. (+bac +nem2) on plant biomass and mineral nutrient accumulation of $P$. pinaster grown for $60 \mathrm{~d}$ on solid medium with phytate as the sole source of $\mathrm{P}$ (data given in Fig. 1)

\begin{tabular}{lllll}
\hline Variation source & \multicolumn{2}{l}{ Plant biomass } & & \multicolumn{2}{l}{ Total P accumulation } \\
\cline { 2 - 4 } & Roots & Shoots & Roots & Shoots \\
\hline Plant status & $>0.05$ & $>0.05$ & $>0.05$ & $>0.05$ \\
Inoc. treatments & $<0.01$ & $<0.01$ & $<0.01$ & $<0.01$ \\
Interaction & $>0.05$ & $>0.05$ & $>0.05$ & $>0.05$ \\
\hline
\end{tabular}

the mycorrhizal status did not modify significantly the $\mathrm{P}$ accumulation in roots and shoots, contrary to the inoculation treatments (Table 3, Fig. 1b). This was due to the dramatic effect of both the nematode species as the amounts of $\mathrm{P}$ accumulated in roots or shoots of the plants grown without nematodes (none and + bac) were not significantly different (Fig 1b). Compared to the averaged $\mathrm{P}$ amounts calculated in plants grown in sterile conditions and with bacteria only, the nematodes strongly increased $\mathrm{P}$ accumulation in both $\mathrm{NM}$ and $\mathrm{M}$ plants. On average, the increase was $+174 \%$ (roots) and $+176 \%$ (shoots) in NM plants and $+205 \%$ (roots) and $+147 \%$ (shoots) in M plants (Fig. 1b).

Plotting the individual values of total plant $\mathrm{P}$ accumulation against the root surface area (Fig. 2a) showed that plant $\mathrm{P}$ accumulation in NM plants, whether grown in control conditions (treatment none) or inoculated with bacteria only (treatment + bac), increased linearly with the root surface ( $\mathrm{r} 2=0.27, p=0.05$ ). The presence of the fungus did not change this relationship in absence of nematodes. In contrast, the values measured in NM and $\mathrm{M}$ plants grown in the presence of either nematode species did not fit in with the relationship established in the absence of nematodes. An increase of root surface went with a proportional increase of accumulated $\mathrm{P}$ in NM plants whereas $M$ plants exhibited a more variable and stronger increase of $\mathrm{P}$ accumulation relative to their root surface (Fig. 2a). As shown in Fig. 2b, the mean values of the ratio of $\mathrm{P}$ accumulation per unit of root surface calculated in NM and M plants without nematodes were not significantly different, indicating that the fungus alone was not able to enhance $\mathrm{P}$ uptake from the medium. However, the two species of nematodes differently modified the ratio of $\mathrm{P}$ accumulation per unit of root surface. In NM plants, only plants with Acrobeloides sp. displayed a significant increase of this ratio, plants with Rhabditis sp. were intermediate compared to plants without nematodes. In contrast, with M plants, despite a high variability of the data, the two species of nematodes increased significantly the average values of accumulated $P$ per unit of root surface area compared to plants without nematodes, with the highest average calculated in plants grown in the presence of Acrobeloides sp. As shown in Fig. 2c, M plants exhibited significantly higher amounts of glucosamine in their roots, due to the fungal capacity to colonize the root system. M plants from the two nematode treatments presented the highest values of glucosamine contents together with the largest variability of individual data compared to plants from the other treatments. Taken together, the higher variability of plant $\mathrm{P}$ accumulation observed in $\mathrm{M}$ plants than in NM plants in presence of nematodes (Fig. 2a), suggests that the roots may not be solely responsible for $\mathrm{P}$ uptake and that the mycelium could play a significant role.

Evolution of bacterial and nematode populations in presence of $P$. pinaster seedlings

Compared to the initial amount of bacteria, $1.3 \pm 0.1 \times$ $10^{6}$ cells, added to each inoculated plant bacterial populations dramatically increased in the rhizosphere of plants after $60 \mathrm{~d}$ of co-inoculation by factors ranging from 36 to 54 (Table 4). The NM plants presented the highest level of bacterial populations and the presence of nematodes tended to decrease it. The presence of the fungus together with nematodes significantly decreased bacterial populations by $32 \%$ compared to NM plants with + bac treatments. Compared to their initial population, the nematodes Rhabditis sp. increased by a factor of 45 and 27 in NM and M plants respectively. The populations of Acrobeloides sp. were twice as high as those of Rhabditis sp., and increased by a factor of 91 
Fig. 2 Relationship between (a) total $\mathrm{P}$ accumulation and root surface area, (b) $\mathrm{P}$ absorption efficiency per root surface $\left(\mathrm{cm}^{2}\right)$ and (c) glucosamine $\left(\mu \mathrm{g} / \mathrm{mg}^{-1}\right.$ of dry weight) measured in $P$. pinaster plants of different status, either non-

mycorrhizal (NM) or mycorrhizal (M) with the ectomycorrhizal fungus $H$. cylindrosporum, supplied with phytate in solid medium for $60 \mathrm{~d}$. Two-month old NM or $\mathrm{M}$ plants were cultivated with different inoculation treatments that were either no addition (none), or addition of phytate-mineralizing bacteria only (+bac) or together with bacterial feeding nematodes $(+\mathrm{bac}+$ nem 1 and + bac + nem 2 ) (a)

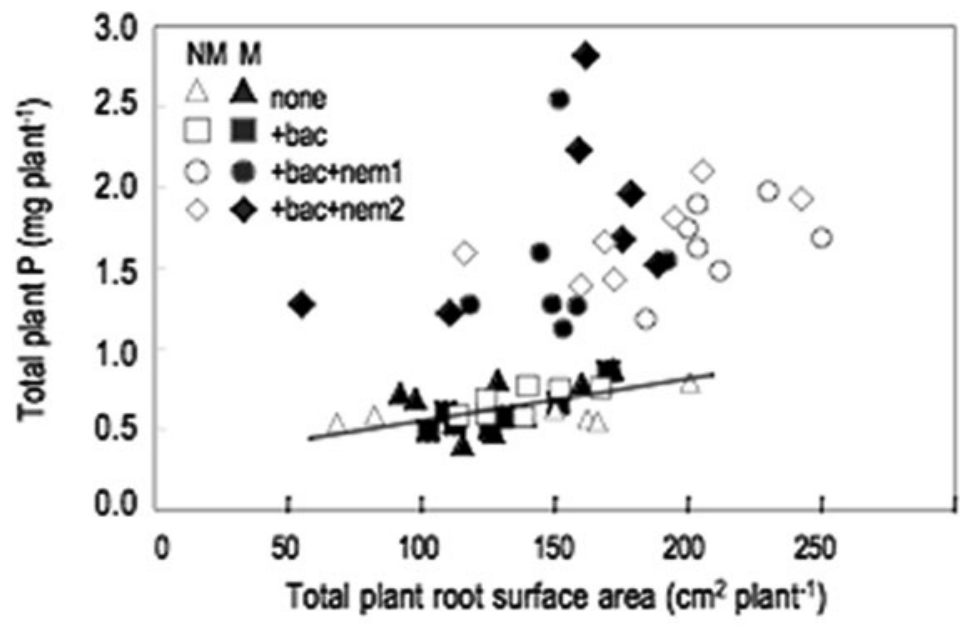

(b)

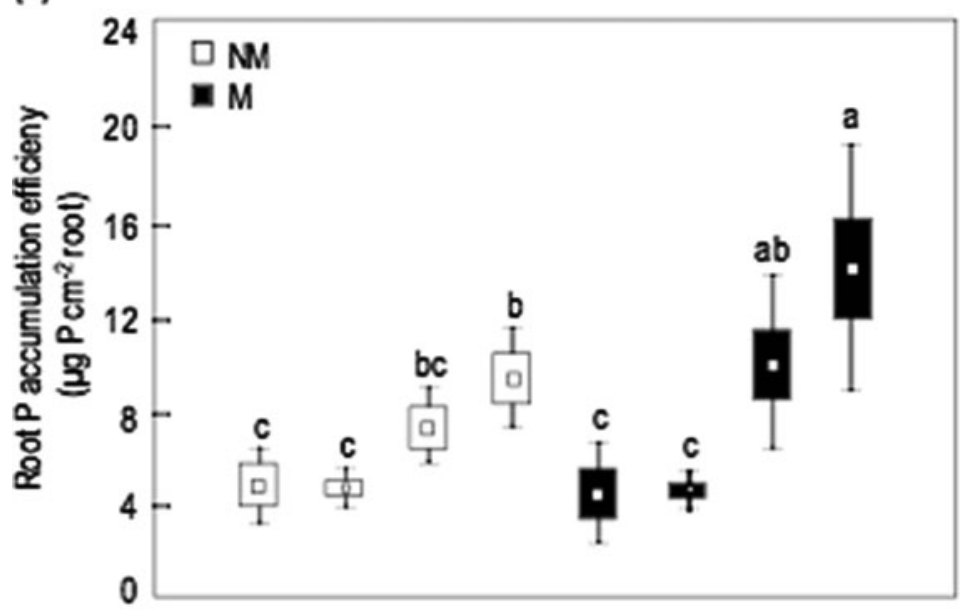

(c)

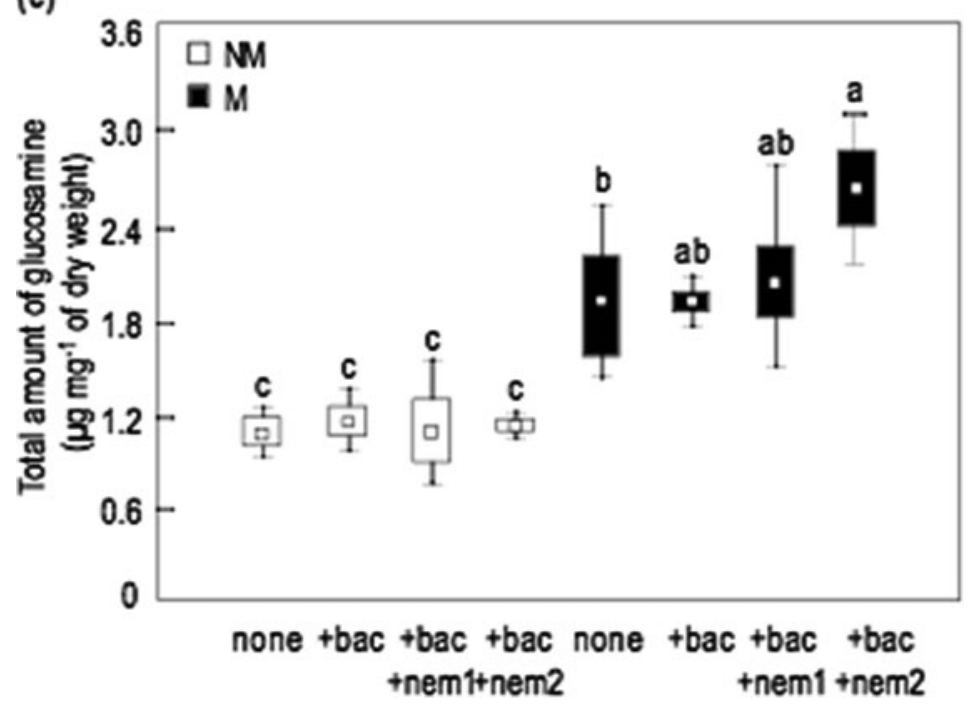


and 75 in NM and M plants respectively, during the growth period. Although the nematodes (Rhabditis sp.) were more abundant in NM $(+66 \%)$ than in M plants, their biomass was not significantly different (Table 4). This is due to the higher number of juveniles observed with NM than with M plants.

\section{Discussion}

Effect of plant and ectomycorrhizal symbiosis on bacterial and nematode populations

The presence of the plant in the culture system increased bacterial populations in absence of nematodes (compare Tables 1 and 4). This suggests that the growth of bacteria with phytate as the sole source of $\mathrm{C}$ and $\mathrm{P}$ was limited. The solid medium contained initial low amounts of $\mathrm{Pi}$ (assayed at $50 \mu \mathrm{g}$ per plate) that may have supported the rapid growth of the bacteria observed after $15 \mathrm{~d}$ (Table 1). It may also have contained some available $\mathrm{C}$ sources that contributed to the initial growth of the bacteria. However, once these available sources were used by the bacteria, the growth stopped, indicating that phytate was not a good source of $\mathrm{C}$ for $B$. subtilis. Indeed, the capacity to use phytate as the unique $\mathrm{C}$ and $\mathrm{P}$ source is limited to $0.5 \%$ of culturable bacteria isolated from soil (Richardson and Hadobas 1997). This unability to use phytate as a C source could be due to the action mode of BPP-phytase (PhyC) secreted by B. subtilis. The enzyme produces both $\operatorname{Ins}(2,4,6) \mathrm{P} 3$ and $\operatorname{Ins}(1,3,5) \mathrm{P} 3$ as the major products (Greiner et al. 2002) unusable by bacteria as a $C$ source (Tzvetkov and Liebl 2008). Conversely, when the plant was cultivated with $B$. subtilis, a large number of bacterial cells were observed, especially in absence of the mycorrhizal fungus and nematodes, indicating that the plant was able to supply the $\mathrm{C}$ source. The fungus and the nematodes decreased significantly the size of bacterial populations in the medium. Such a negative effect could be due to the competition for available $\mathrm{C}$ between the fungus and the bacteria, and/or the grazing pressure exerted by these bacteria-feeding nematodes (Ingham et al. 1985; Fu et al. 2005).

As it did for bacteria, the presence of the plant also strongly increased the size of the nematode populations of Rhabditis sp., especially when they are nonmycorrhizal, with a high number of juveniles. This reflects the abundant bacterial resource (Aescht and Foissner 1992; Ettema and Bongers 1993). Conversely, the negative effect of the mycorrhizal symbiosis on nematode abundance $(-66 \%)$ could also derive from the competition for plant $\mathrm{C}$ source between the fungus and the bacterial cells, decreasing in turn the resource for nematodes. On the other hand, the populations of Acrobeloides sp. were more abundant than those of Rhabditis sp in NM and M plants. Cephalobidae (such as Acrobeloides sp) are "general opportunist" whereas Rhabditidae are "enrichment opportunist" (Bongers 1990; Cheng et al. 2011). As discussed by Blanc et al. (2006), under enriched

Table 4 Abundance of phytate-mineralizing bacterial (B. subtilis) and bacterial-feeding nematodes (Rhabditis sp (+bac + nem1) or Acrobeloides sp. (+bac+nem2) populations 60 days after inoculation in the rhizosphere of $P$. pinaster plants, nonmycorrhizal (NM) or mycorrhizal (M) with the ectomycorrhizal

fungus $H$. cylindrosporum, supplied with phytate in solid medium. The initial inoculated populations plant $-{ }^{1}$ for bacteria and nematodes were $1.3 \times 10^{6} \pm 0.1,107 \pm 6$ (Rhabditis sp.) and $98 \pm 7$ (Acrobeloides sp.) respectively

\begin{tabular}{lllll}
\hline Plant status & Treatments & Bacterial cells $\left(\times 10^{6}\right.$ plant $\left.^{-1}\right)$ & Nematodes $\left(\times 10^{3}\right.$ plant $\left.^{-1}\right)$ & Nematode biomass $\left(\mu g\right.$ plant $\left.^{-1}\right)$ \\
\hline NM & + bac & $70 \pm 22 \mathrm{a}$ & & \\
& + bac + nem1 & $60 \pm 19 \mathrm{ab}$ & $4.82 \pm 0.70 \mathrm{~b}$ & $351 \pm 62^{\mathrm{a}}$ \\
& + bac+nem2 & $62 \pm 18 \mathrm{ab}$ & $8.91 \pm 0.97 \mathrm{a}$ & $559 \pm 74$ \\
$\mathrm{M}$ & + bac & $54 \pm 14 \mathrm{ab}$ & & $258 \pm 40$ \\
& + bac + nem1 & $48 \pm 9 \mathrm{~b}$ & $2.90 \pm 0.26 \mathrm{c}$ & $479 \pm 63$ \\
& + bac+nem2 & $47 \pm 7 \mathrm{~b}$ & $7.37 \pm 0.79 \mathrm{a}$ &
\end{tabular}

Data are means \pm standard deviation $(n=7)$ and were compared using one-way ANOVA followed by the Tukey's minimum significant difference test. For each parameter, means significantly different at $P<0.05$ have different letters

${ }^{a}$ Biomass of nematodes was calculated from the size of 500 individuals randomly sampled from the whole population 
conditions such as fertilizer or manure input in soil or breeding on nutrient agar, Rhabditis multiply more than Cephalobidae. However on the long term and in limited resources conditions as in natural soil, Cephalobidae may present higher populations than enrichment opportunists.

\section{$\mathrm{P}$ accumulation and plant growth}

Although the total amounts of P accumulated in NM plants grown in sterile conditions or with bacteria alone were higher than the initial ones, they were not significantly different. These results indicated a low capacity of plants to use $\mathrm{P}$ from phytate, as claimed by numerous authors (Adams and Pate 1992; Findenegg and Nelemans 1993; Hayes et al. 2000; Richardson et al. 2000, 2001a,b). The presence of phytate mineralizing bacteria did not increase significantly the net amount of $\mathrm{P}$ in NM plants. This result demonstrates that the bacteria alone developing in the rhizosphere were not able to provide more $\mathrm{P}$ to the plants despite the observed increase of free $\mathrm{Pi}$ in liquid culture (Fig. S1). This observation does not agree with previous studies showing that the $\mathrm{P}$ nutrition of plants supplied with phytate was improved significantly when the agar medium was inoculated with soil microorganisms or a strain of Pseudomonas fluorescens with phytase activity (Richardson et al. 2001b). Our experimental conditions favored the growth of bacteria and this may have led to a rapid immobilization of $\mathrm{Pi}$ in bacterial biomass remaining unavailable for plants. The presence of $H$. cylindrosporum, whether or not with bacteria, did not modify $\mathrm{P}$ availability to plants. This is in agreement with the poor ability of the fungus to use phytate as the sole source of $\mathrm{P}$ (Table S1) and its low ability to release phytase in its culture medium (Louche et al. 2010).

The grazing activity of both nematode species upon the phytate-mineralizing bacteria dramatically increased total $\mathrm{P}$ accumulation in roots and shoots. The observed $\mathrm{P}$ accumulation and growth in shoots of NM plants was comparable to the values obtained when plants were grown in solid medium containing a non limiting $\mathrm{P}$ availability supplied as $\mathrm{KH}_{2} \mathrm{PO}_{4}$ (Irshad, unpublished results). This indicates that the grazing activity upon populations of phytate-mineralizing bacteria could be as efficient as the production of transgenic plants expressing and releasing into the external medium the Aspergillus phytase (Richardson et al. 2001a).
However, NM plants with Acrobeloides sp. did not significantly accumulate more biomass in roots and shoots than plants grown in sterile conditions or with bacteria alone despite the supplementary amount of $\mathrm{P}$ accumulated in plants. These plants presented also the highest level of nematode population that may have drained more carbon exudates than when the plants were grown with the other nematode species. Finally, this high carbon allocation to the food web (Bonkowski et al. 2001) could have resulted in less carbon storage in plants and less growth. The same mechanism could apply in M plants where the presence of Acrobeloides sp. did not increase plant biomass compared to control plants despite a higher plant $\mathrm{P}$ accumulation. Here, abundance of Acrobeloides was not significantly decreased by mycorrhizal association and the level of fungal colonization, estimated from glucosamine concentrations in roots, was the highest. Therefore, this high density of nematodes together with ectomycorrhizal hyphae may also have lead to competition for carbon at the expense of plant growth.

Effect of food web on root growth and $\mathrm{P}$ acquisition

Our results showed that $\mathrm{M}$ plants presented values of root length and surface area lower than those measured in NM plants. This agrees with the effect of mycorrhizal symbiosis (Jentschke et al. 1995) and of this fungal species (Aquino and Plassard 2004). However, the presence of nematodes induced always a positive effect on root growth parameters, whatever the status of the plant, mycorrhizal or non-mycorrhizal. These results are not in agreement with the studies of Jentschke et al. (1995) and Bonkowski et al. (2001) who reported the persistence of the negative effect of ectomycorrhizal symbiosis on root development of Norway spruce seedlings (Picea abies) after plant inoculation with either bacteria or bacteria plus protozoa. Our results showed that nematodes exerted a positive influence on root growth and ramification in the presence ectomycorrhizal fungus, suggesting that they could have a different role from protozoa regarding this aspect.

The presence of nematodes also strongly modified the relationship between the root surface area and total $\mathrm{P}$ accumulation by simultaneously increasing the surface area and $\mathrm{P}$ accumulation, especially in NM plants. The simplest hypothesis to explain this change is that the $\mathrm{P}$ availability from phytate to the roots was strongly increased by the grazing activity of nematodes. This 
effect could arise from several causes. Firstly, this could come from the liberation of free Pi or other sources of organic P accumulated in bacteria and released into the medium by grazing. The free Pi will be directly available whereas the organic $\mathrm{P}$ could be easily used by the phosphatases released by roots as shown in wheat and Arabidopsis (Richardson et al. 2000, 2001a). Secondly, enhanced Pi availability by grazing could result from the higher turn-over of bacterial populations in the presence of nematodes than in their absence. Indeed, although the final number of bacteria was lower in plants with nematodes than without nematodes, more abundant bacterial populations have been necessary to support the nematode growth. Therefore, together with their growth, the bacterial populations could have used more phytate resulting in turn in a higher release of free Pi into the medium than with no nematodes present. Also, due to their moving and transporting capacities of bacteria (Chen et al. 2007), the nematodes may have greatly increased the capacity of the bacteria to access phytate throughout the whole solid medium. Finally, plant $\mathrm{P}$ could have arisen from nematode life cycling and dead organisms as it was shown that NM Betula pendula seedlings were able to accumulate $\mathrm{P}$ from nematode necromass (Perez-Moreno and Read 2001). All these effects could have occurred during the experiment, resulting in the observed enhanced $\mathrm{P}$ availability to the plants.

The presence of the ectomycorrhizal fungus modified even more strongly the relationship between the root surface area and plant $\mathrm{P}$ accumulation by enhancing the root efficiency to take up phosphorus from the medium. All the effects leading to an enhanced $P$ availability by nematode grazing proposed in NM plants may apply in M plants. However, the fungus could add a supplementary effect, which is a better exploration of the medium than plant roots. Such a positive effect of this fungal species was reported by Aquino and Plassard (2004) in P. pinaster plants grown at the surface of a thin layer of soil. It was attributed to a greater medium exploration by the hyphae compared to roots together with a "fungal pathway" of Pi uptake in M plants. This means that although an agar medium was used in our experiment, medium exploration by hyphae in M plants or by roots in NM plants is an important feature to take up $\mathrm{Pi}$, indicating that $\mathrm{Pi}$ was probably not freely mobile in the medium.
In conclusion, our data strongly support the possible role played by the microbial loop to enhance $\mathrm{P}$ mineralization from organic $\mathrm{P}$ and $\mathrm{P}$ availability to plants. This positive role is based on the assumption that newly grown bacteria are able to mobilize nutrients that are not easily accessible to plants (such as phytate), which are then made available to plants by bacterial grazers (Clarholm, 2005; Kuikman et al. 1991). Although the mechanisms leading to the release of available Pi from the grazing activity of nematodes upon phytate-mineralizing bacteria remain to be elucidated, our data demonstrated for the first time the importance of the microbial loop to enhance $\mathrm{P}$ availability from phytate, which is recognized as the most poorly available organic $\mathrm{P}$ compounds to plants (Richardson et al. 2000). Our results open a new route to manage $\mathrm{P}$ nutrition of plants that needs now further studies at the field level.

Acknowledgement Usman Irshad was supported by a grant from the Higher Education Commission of Pakistan. We thank Dr Maria Sels for English reading and corrections.

\section{References}

Adams MA, Pate JS (1992) Availability of organic and inorganic forms of phosphorus to lupins (Lupinus spp). Plant Soil 145:107-113

Aescht T, Foissner W (1992) Effect of mineral and organic fertilisers on the microfauna in a high-altitude reforestation trial. Biol Fertil Soils 13:17-24

Ali MA, Louche J, Legname E, Duchemin M, Plassard C (2009) Pinus pinaster seedlings and their fungal symbionts show high plasticity in phosphorus acquisition in acidic soils. Tree Physiol 29:1587-1597

Aquino MT, Plassard C (2004) Dynamics of ectomycorrhizal mycelial growth and $\mathrm{P}$ transfer to the host plant in response to low and high soil $\mathrm{P}$ availability. FEMS J Microbiol Ecol 48:149-156

Barnett GM (1994) Phosphorus forms in animal manures. Biores Technol 49:139-147

Bernard EC (1992) Soil nematode biodiversity. Biol Fertil Soils 14:99-103

Blanc C, Sy M, Djigal D, Brauman A, Normand P, Villenave C (2006) Nutrition on bacteria by bacterial-feeding nematodes and consequences on the structure of soil bacterial community. Eur J Soil Biol 42:70-78

Bongers T (1990) The maturity index: an ecological measure of environmental disturbance based on nematode species composition. Oecologia 83:14-19

Bonkowski M, Jentschke G, Scheu S (2001) Contrasting effects of microbes in the rhizosphere: interactions of mycorrhiza (Paxillus involutus (Batsch) Fr.), naked amoebae 
(Protozoa) and Norway Spruce seedlings (Picea abies Karst.). Appl Soil Ecol 18:193-204

Bonkowski M, Villenave C, Griffiths B (2009) Rhizosphere fauna: the functional and structural diversity of interactions of soil fauna with plant roots. Plant Soil 321:213-233

Casarin V, Plassard C, Hinsinger P, Arvieu J-C (2004) Quantification of ectomycorrhizal effects on the bioavailability and mobilization of soil $\mathrm{P}$ in the rhizosphere of Pinus pinaster. New Phytol 163:177-195

Chen X, Liu M, Hu F, Mao X, Li H (2007) Contributions of soil microfauna (protozoa and nematodes) to rhizosphere ecological functions. Acta Ecol Sin 27:3132-3143

Cheng Y, Jiang Y, Griffiths BS, Li D, Hu F, Li H (2011) Stimulatory effects of bacterial-feeding nematodes on plant growth vary with nematodes species. Nematology 13:369-372

Clarholm M (2005) Soil protozoa: an under-researched microbial group gaining momentum. Soil Biol Biochem 37:811817

Cordell D, Drangert J-O, White S (2009) The story of phosphorus: global food security and food for thought. Glob Environ Chang 19:292-305

Debaud JC, Gay G (1987) In vitro fruiting under controlled conditions of the ectomycorrhizal fungus Hebeloma cylindrosporum associated with Pinus pinaster. New Phytol 105:429-435

Dickie IA, Yeates GW, St John MG et al (2011) Ecosystem service and biodiversity trade-offs in two woody successions. J Appl Ecol 48:926-934

Ettema CH, Bongers T (1993) Characterization of nematode colonization and succession in disturbed soil using the maturity index. Biol Fertil Soils 16:79-85

Fu SL, Ferris H, Brown D, Plant R (2005) Does the positive feedback effect the nematodes on the biomass and activity of their bacteria prey vary with nematodes species and population size? Soil Biol Biochem 37:1979-1987

Findenegg GR, Nelemans JA (1993) The effect of phytase on the availability of phosphorus from myo-inositol hexaphosphate (phytate) for maize roots. Plant and Soil 154:189-196

George TS, Richardson AE, Smith JB, Hadobas PA, Simpson RJ (2005) Limitations to the potential of transgenic Trifolium subterraneum L. plants that exude phytase, when grown in soils with a range of organic phosphorus content. Plant and Soil 278:263-274

Greiner R, Farouk A, Alminger ML, Carlsson NG (2002) The pathway of dephosphorylation of myo-inositol hexakisphosphate by phytate-degrading enzymes of different Bacillus spp. Can J Microbiol 48:986-997

Harrison AF (1987) Soil organic phosphorus: a review of world literature. $\mathrm{CAB}$ Int, Wallingford

Hayes JE, Simpson RJ, Richardson AE (2000) The growth and phosphorus utilization of plants in sterile media when supplied with inositol hexaphosphate, glucose 1-phosphate or inorganic phosphate. Plant and Soil 220:165-174

Hinsinger P (2001) Bioavailability of soil inorganic P in the rhizosphere as affected by root-induced chemical changes: a review. Plant and Soil 237:173-195

Ingham RE, Trofymow JA, Ingham ER, Coleman DC (1985) Interactions of bacteria, fungi, and their nematode grazers: Effects on nutrient cycling and plant growth. Ecol Monogr 55:119-140
Irshad U, Villenave C, Brauman A, Plassard C (2011) Grazing by nematodes on rhizosphere bacteria enhances nitrate and phosphorus availability to Pinus pinaster seedlings. Soil Biol Biochem 43:2121-2126

Jentschke G, Bonkowski M, Godbold DL, Scheu S (1995) Soil protozoa and forest tree growth: non-nutritional effects and interaction with mycorrhizas. Biol Fertil Soils 20:263269

Jorquera MA, Hernández MT, Rengel Z, Marschner P, Mora MDLL (2008a) Isolation of culturable phosphobacteria with both phytate-mineralization and phosphate-solubilization activity from the rhizosphere of plants grown in a volcanic soil. Biol Fertil Soils 4:1025-1034

Jorquera M, Martinez O, Maruyama F, Marschner P, Mora MDLL (2008b) Current and future biotechnological applications of bacterial phytases and phytase-producing bacteria. Microbes Environ 23:182-191

Kuikman PJ, Jansen AG, Van Veen JA (1991) ${ }^{15}$ N-Nitrogen mineralization from bacteria by protozoan grazing at different soil moisture regimes. Soil Biol Biochem 23:193200

Louche J, Ali MA, Cloutier-Hurteau B, Sauvage FX, Quiquampoix H, Plassard C (2010) Efficiency of acid phosphatases secreted from the ectomycorrhizal fungus Hebeloma cylindrosporum to hydrolyse organic phosphorus in podzols. FEMS Microbiol Ecol 73:323-335

Marschner P, Crowley D, Rengel Z (2011) Rhizosphere interactions between microorganisms and plants govern iron and phosphorus acquisition along the root axis - model and research methods. Soil Biol Biochem 43:883-894

Mousain D, Bousquet N, Polard C (1988) Comparison of phosphatase activities in ectomycorrhizal homobasidiomycetes cultured in vitro. Eur J Forest Pathol 18:299-309

Mullaney EJ, Ullah AHJ (2003) The term phytase comprises several different classes of enzymes. Biochem Biophys Res Commun 312:179-184

Mullaney EJ, Ullah AHJ (2007) Phytases: attributes, catalytic mechanisms and applications. In: Turner BL, Richardson AE, Mullaney EJ (eds) Inositol phosphates: linking agriculture and the environment. CAB Int, Wallingford, pp 97-110

Ohno T, Zibilske L (1991) Determination of low concentrations of phosphorus in soil extracts using malachite green. Soil Sci Soc Am J 55:892-895

Peperzak P, Caldwell AG, Hunziker RR, Black CA (1959) Phosphorus fractions in manures. Soil Sci 87:293-302

Perez-Moreno J, Read DJ (2001) Nutrient transfer from soil nematodes to plants: a direct pathway provided by the mycorrhizal mycelial network. Plant Cell Environ 24:12191226

Plassard C, Dell B (2010) Phosphorus nutrition of mycorrhizal trees. Tree Physiol 30:1129-1139

Raboy V (2007) Seed phosphorus and the development of lowphytate crops. In: Turner BL, Richardson AE, Mullaney EJ (eds) Inositol phosphates: linking agriculture and the environment. CAB Int, Wallingford, pp 111-132

Richardson AE, Hadobas PA (1997) Soil isolates of Pseudomonas spp. that utilize inositol phosphates. Can J Microbiol 43:509-516

Richardson AE, Hadobas PA, Hayes JE (2000) Acid phosphomonoesterase and phytase activities of wheat (Triticum 
aestivum I.) roots and utilization of organic phosphorus substrates by seedlings grown in sterile culture. Plant Cell Environ 23:397-405

Richardson AE, Hadobas PA, Hayes JE (2001a) Extracellular secretion of Aspergillus phytase from Arabidopsis roots enables plants to obtain phosphorus from phytate. Plant $\mathrm{J}$ 25:641-649

Richardson AE, Hadobas PA, Hayes JE, O'Hara CP, Simpson RJ (2001b) Utilization of phosphorus by pasture plants supplied with myo-inositol hexaphosphate is enhanced by the presence of soil micro-organisms. Plant and Soil 229(1):4756

Richardson AE, George TS, Jakobsen Y, Simpson RJ (2007) Plant utilization of inositol phosphates. In: Turner BL, Richardson AE, Mullaney EJ (eds) Inositol phosphates: linking agriculture and the environment. CAB Int, Wallingford, pp 242-260

Smith SE, Jakobsen Y, Grønlund M, Smith FA (2011) Roles of arbuscular mycorrhizas in plant phosphorus nutrition: interactions between pathways of phosphorus uptake in arbuscular mycorrhizal roots have important implications for understanding and manipulating plant phosphorus acquisition. Plant Physiol 156:1050-1057

Tatry MV, Kassis EE, Lambilliotte R, Corratge C, van Aarle I, Amenc LK, Alary R, Zimmermann S, Sentenac H, Plassard C (2009) Two differentially regulated phosphate transporters from the symbiotic fungus Hebeloma cylindropsporum and phosphorus acquisition by ectomycorrhizal Pinus pinaster. Plant J 57:1092-1102
Tzvetkov MV, Liebl W (2008) Phytate utilization by genetically engineered lysine-producing Corynebacterium glutamicum. J Biotechnol 134:211-217

Turner B (2007) Inositol phosphates in soil: amounts, forms and significance of the phosphorylated inositol stereoisomers. In: Turner BL, Richardson AE, Mullaney EJ (eds) Inositol phosphates: linking agriculture and the environment. $\mathrm{CAB}$ Int, Wallingford, pp 186-206

Turner BL, Leytem AB (2004) Phosphorus compounds in sequential extracts of animal manures: chemical speciation and a novel fractionation procedure. Environ Sci Tech 38:6101-6108

Turner BL, Paphazy MJ, Haygarth PM, McKelvie ID (2002) Inositol phosphates in the environment. Philos Trans R Soc Lond B 357:449-469

Villenave C, Ekschmitt K, Nazaret S, Bongers T (2004) Interactions between nematodes and microbial communities in a tropical soil following manipulation of the soil food web. Soil Biol Biochem 36:2033-2043

Vignon C, Plassard C, Mousain D, Salsac L (1986) Assay of fungal chitin and estimation of mycorrhizal infection. Physiologie Vegetale 24:201-207

Yip W, Wang L, Cheng C, Wu W, Lung S, Lim BL (2003) The introduction of a phytases gene from Bacillus subtilis improved the growth performance of transgenic tobacco. Biochem Biophys Res Commun 310:1148-1154

Zuckerman BM, Brzeski MW, Deubert KH (1967) English translation of selected east European papers in nematology. Univ Massachusetts, East Wareham 


\section{Supplementary Material}

\section{Supplementary Method description:}

Chitin assay: Once the acid hydrolysis was completed, the $\mathrm{pH}$ of the hydolysate was adjusted to approximately 4.5 by addition of sodium acetate $1.25 \mathrm{M}(1 / 5, \mathrm{v} / \mathrm{v})$ to enable the development of the colorimetric assay of glucosamine residues. The colorimetric assay involves two different stages: the glucosamine residues are first deaminated by $\mathrm{HNO}_{2}$ to produce 2-5 anhydromannoses, molecules with a free aldehyde group on carbon 1 . These compounds then react with MBTH, a specific reactive of aldehyde groups, to give a blue colour in the presence of $\mathrm{FeCl}_{3}$. After acid hydrolysis, it is possible to assay aliphatic aldehyde groups that do not result from the deamination of amino sugars. The absence of $\mathrm{HNO}_{2}$ during incubation enables one to determine the amount of aliphatic aldehydes present in the solution. As a consequence, the actual amount of amino sugars may be calculated from the difference between the absorbance values obtained with and without the action of $\mathrm{HNO}_{2}$ on the same sample.

Colorimetric assay: the total absorbance (aldehydes + amino sugars) was measured by adding $1 \mathrm{ml} \mathrm{KHSO}_{4} 5 \%(\mathrm{w} / \mathrm{v})$ and $1 \mathrm{ml} \mathrm{NaNO} 25 \%(\mathrm{w} / \mathrm{v})$ to $1 \mathrm{ml}$ of solution containing the residues (production of $\mathrm{HNO}_{2}$ ). The absorbance due to aliphatic aldehyde groups was measured by replacing $\mathrm{NaNO}_{2} 5 \%$ by $1 \mathrm{ml}$ of ultrapure water. After shaking, the mixture was allowed to stand for $15 \mathrm{~min}$ (deamination time). Then $1 \mathrm{ml}$ of $\mathrm{H}_{2} \mathrm{NSO}_{3} \mathrm{NH}_{4} 12.5 \%$ (w/v) was added to eliminate the excess of $\mathrm{HNO}_{2}$. After vigorous shaking ( $5 \mathrm{~min}$ ), $1 \mathrm{ml} \mathrm{MBTH} 0.5 \%(\mathrm{w} / \mathrm{v})$ was added. Reaction time was $1 \mathrm{~h}$ without shaking before adding $1 \mathrm{ml} \mathrm{FeCl}{ }_{3}, 6 \mathrm{H}_{2} 00.83 \%$ (w/v). The blue colour was allowed to develop for $30 \mathrm{~min}$ and was stable for up to $24 \mathrm{~h}$. The absorbance was measured at $653 \mathrm{~nm}$, using a sample without glucosamine as blank. All chemical were from Sigma. 
Table S1. Root architecture (length, surface area, number of tips and forks) and amounts of total biomass, total $\mathrm{N}$ and total $\mathrm{P}$ measured in two-month old $P$. pinaster plants of different status, either non-mycorrhizal (NM) or mycorrhizal (M) with the ectomycorrhizal fungus $H$. cylindrosporum, at the time of transfer in solid medium containing phytate as the sole source of $P$. Values are the means $(n=6)$ with standard deviation between brackets.

Root architecture

\begin{tabular}{|c|c|c|c|c|c|c|c|}
\hline $\begin{array}{l}\text { Plant } \\
\text { status }\end{array}$ & $\begin{array}{l}\text { Plant } \\
\text { parts }\end{array}$ & $\begin{array}{l}\text { Length } \\
(\mathrm{cm} \\
\text { plant }^{-1} \text { ) }\end{array}$ & $\begin{array}{l}\text { Surface } \\
\text { area } \\
\left(\mathrm{cm}^{2}\right. \\
\left.\text { plant }^{-1}\right)\end{array}$ & \multicolumn{3}{|c|}{ (number plant ${ }^{-1}$ ) } & $\begin{array}{l}\text { Total } \\
\mathrm{P}\end{array}$ \\
\hline NM & Roots & $\begin{array}{l}250 \\
(30)\end{array}$ & $\begin{array}{l}81 \\
(11)\end{array}$ & $\begin{array}{l}670 \\
(89)\end{array}$ & $\begin{array}{l}1627 \\
(329)\end{array}$ & $\begin{array}{l}152 \\
(28)\end{array}$ & $\begin{array}{l}0.07 \\
(0.02)\end{array}$ \\
\hline & Shoots & & & & & $\begin{array}{l}258 \\
(20)\end{array}$ & $\begin{array}{l}0.23 \\
(0.03)\end{array}$ \\
\hline $\mathrm{M}$ & Roots & $\begin{array}{l}252 \\
(34)\end{array}$ & $\begin{array}{l}82 \\
(13)\end{array}$ & $\begin{array}{l}906 \\
(195)\end{array}$ & $\begin{array}{l}2102 \\
(314)\end{array}$ & $\begin{array}{l}172 \\
(15)\end{array}$ & $\begin{array}{l}0.08 \\
(0.01)\end{array}$ \\
\hline & Shoots & & & & & $\begin{array}{l}282 \\
(30)\end{array}$ & $\begin{array}{l}0.31 \\
(0.07)\end{array}$ \\
\hline
\end{tabular}


Table S2. Growth and P accumulation in the ectomycorrhizal fungus Hebeloma

cylindrosporum grown for $24 \mathrm{~d}$ in liquid medium containing either orthophosphate or organic $\mathrm{P}$ supplied as $\mathrm{KH}_{2} \mathrm{PO}_{4} 1 \mathrm{mM}$ (Pi) or sodium-phytate $1 \mathrm{mM}$ (Phytate). Given values are means $(n=7)$ and different small letters denote significant effect of treatments (one way ANOVA followed by Tukey's test).

The medium contained nitrate $(6 \mathrm{mM})$ as the sole $\mathrm{N}$ source and glucose $(55 \mathrm{mM})$ as carbon source.

\begin{tabular}{llll}
\hline P source & DW (mg/thallus) & $\begin{array}{l}\text { Total P concentration } \\
(\mathrm{mg} / \mathrm{g} \mathrm{DW})\end{array}$ & $\begin{array}{l}\text { Total P accumulation } \\
(\mathrm{mg} / \text { thallus })\end{array}$ \\
\hline $\mathrm{Pi}$ & $5.3 \mathrm{a}$ & $0.269 \mathrm{a}$ \\
Phytate & $10 \mathrm{~b}$ & $3.4 \mathrm{~b}$ & $0.033 \mathrm{~b}$ \\
\hline$P$-values & $<01$ & $<0.05$ & $<0.01$ \\
\hline
\end{tabular}


- Bacterial growth

$\square$ Free $[\mathrm{Pi}]$ in culture medium

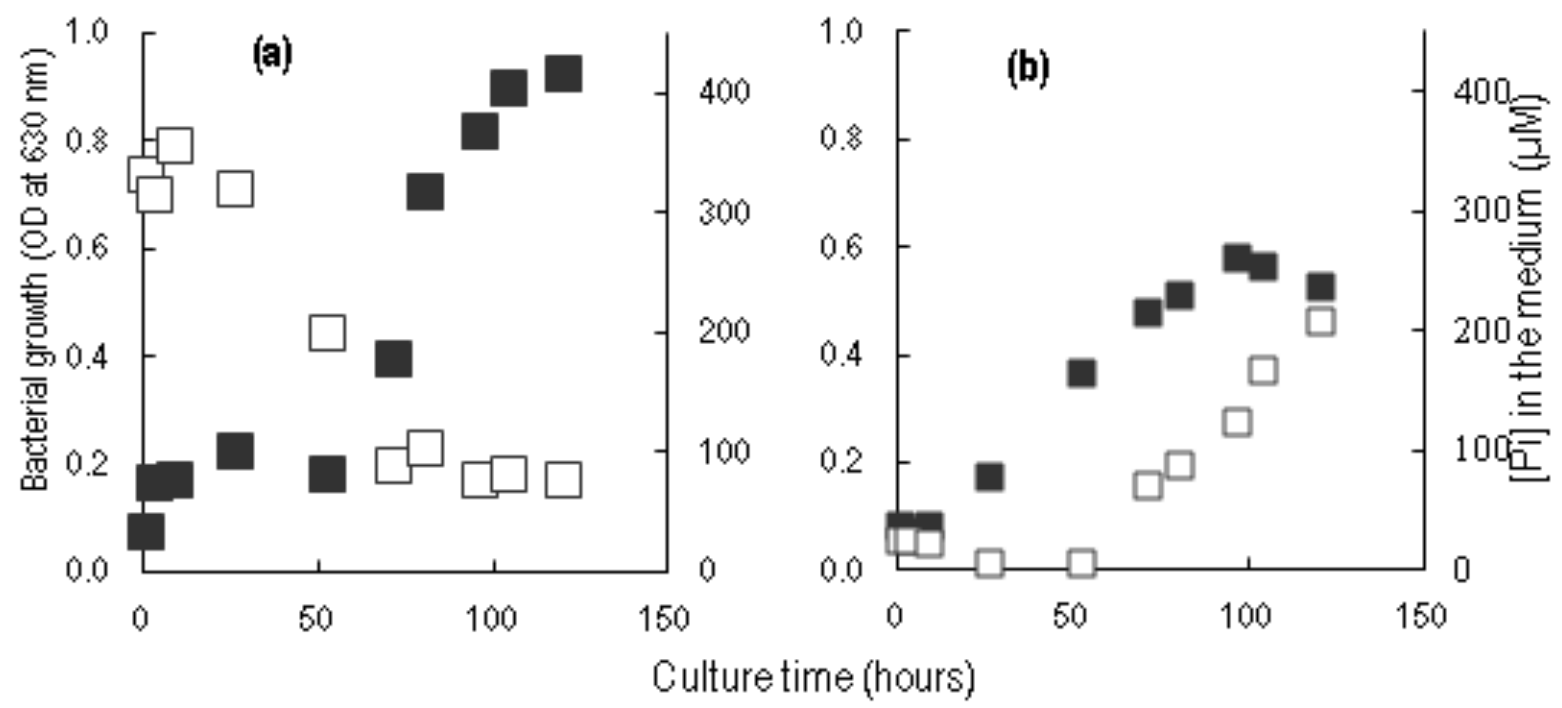

Figure S1. Bacterial growth (estimated from OD measurements at $630 \mathrm{~nm}$ ) and Pi concentration in liquid medium inoculated with the phytate-mineralizing bacteria, Bacillus subtilis and containing (a) $\mathrm{KH}_{2} \mathrm{PO}_{4}(1 \mathrm{mM})$ or (b) sodium-phytate $(6 \mathrm{mM})$ as the sole source of $\mathrm{P}$. The culture medium contained nitrate $(1 \mathrm{mM})$ as the sole source of $\mathrm{N}$ and glucose $(55 \mathrm{mM})$ as carbon source. 